\title{
An Intersectional Feminist Reading of Bapsi Sidhwa's Water
}

\author{
Numaira Hamid Khan \\ Department of Intercultural Anglophone Studies (English Department) \\ University of Bayreuth, Germany
}

\begin{abstract}
Intersectionality has been recognized and widely taken by interdisciplinary fields that include Cultural studies, American studies, and Media studies to demonstrate a range of social issues. It focuses on the experiences of people in a different social and political context. The intersectional framework confronts significant social division axes that include race, class, gender, and disability that function together and influence each other. These social axes operate the power structures of a particular society that can cause inequality and discrimination. In literary studies, women representation is no more confined to European and American academic writings. Within the feminist framework, the South Asian fiction writers also demonstrate a feminist approach in their works. Pakistani authors have indicated religion's exploitation as one of the central intersectional tropes in their literary work. Bapsi Sidhwa's is one of the prominent feminist voices from Pakistan in diasporic English Literature. One of her novels, Water (2006), is based on Deepa Mehta's award-winning film, explores the life of the marginal and subaltern Hindu widows in India. The novel provides an insight into the intersectional nature of the Indian Hindu widows in a patriarchal society of a subcontinent where different power domains hold and impose dominant hierarchies. The paper's objective is to highlight the intersection of religion, gender, caste and politics against the backdrop of the Indian anti-colonial movement. It shows how power relations can manipulate cultural norms and use religion as a powerful tool to establish its hegemonic control over these marginalized widows who suffer as silent victims.
\end{abstract}

Keywords: Intersectionality, Feminist studies, Power structures \& Literature

Human experiences reveal that every event indicates various factors that create and trigger complex discrimination among different communities. The popular idea of commitment to social justice and equity is a systematic discourse. However, the underlying structures that are responsible for providing justice, equity to diversity are seldom articulated. According to the political and social climate, hierarchies are established that frame policy 
concerned with structures of injustice and power manipulation. The emergence of the concept of Intersectionality as a conceptual tool reflects power struggles that counter various oppressions. One of the scholars, Sirma Bilge, mentions Thornton Dill \& Zambrano (2009) in one of her writings, Intersectionality Undone, elaborate the concept of Intersectionality as "a theory and praxis, an analytical and political tool elaborated by less powerful social actors facing multiple minoritization (...) (Bilge:410). People political, social, and cultural lives operate on various axes and the organization of power shape or manipulate these structures that can bring havoc in a particular set up.

With the growing concern for the issues of differences among women, Intersectionality aims to address and recognize multiple positions of everyday lives. The term intersectionality is coined initially by Kimberle Crenshaw in 1989, who contributed to both feminist and anti-racist discourse by highlighting the Black women experiences. It touches the interconnection of various forms of exclusion and subordination by making the power relations visible and crucial to all those interconnections. In today's world, women studies are not merely limited to focus on gender. It captures multiple identities, reasons of exclusion and experiences of subordination. Kathy Davis, in one of her articles, Intersectionality as a buzzword, defines the concept as "(it is) the interaction between gender, race, and other categories of difference in individual lives, social practices, institutional arrangements, and cultural ideologies and the outcomes of these interactions in terms of power" (Davis:68).

Despite the theoretical complexities of Intersectionality, it plays a significant role in the field of feminist analysis. The reason for the success of Intersectionality within the feminist theory, in the words of Kathy Davis, is that" (its) focus on a pervasive and fundamental concern in feminist theory, its provision of novelty (...) for further critique and elaboration" (Davis:169). The issues of differences among women in the backdrop of feminism have been addressed on two different strands. The framework of Intersectionality addresses these strands by focusing on various categories of inequality that reveals women marginalization. Within Western feminist inquiry, the first strand focuses on race, class, and gender that affect women of colour within white supremacy and poverty-stricken women's struggle. However, the emphasis on power relations or power structures in women's social lives where race, class, and gender interact is the second strand's focus. These different axes or categories are intertwined, providing a centrality to know differences and diversity issues. 


\section{(II)}

The term intersectionality has been widely recognized in various places and locations. It is a well-established principle in feminist studies. In the words of Patricia Hill Collins and Sirma Bilge, "Intersectionality as an analytical tool gives people better access to the complexity of the world and themselves" (Collins \& Bilge:2). However, the multiple dimensions of social life expand the analysis that demands a complex and challenging methodological approach. Despite certain ambiguities and complexity in methodology, in the words of Leslie McCall, "the overall methodology is feminist and interdisciplinary in orientation, but the methods and specific subject matters(..)because particular methods are an approach to particular subject matters" (McCall:1795). Thus, every social and political life is shaped and understood by various factors.

Similarly, women from various contexts have distinctive experiences and have multiple reasons for subordination in diverse social locations. For instance, the black woman's experience from a gender perspective focused on white women and race studies reveals the struggle against black men. In the words of Patricia Hill Collins and Sirma Bilge, "Black women's use of intersectionality as an analytical tool emerged in response to these challenges" (Collins \& Bilge:03). In this way, every lived experience is distinct from conflicting dynamics.

Like the social division of class, race, gender, and ethnicity are not confined to America and European nations. Similarly, the study of Intersectionality as an analytic tool is not a new phenomenon. One of the prominent examples from $19^{\text {th }}$ century colonial India is the published online work (2015) of Savitribai Phule (1831-1897) titled Six Reasons Every Indian Feminist Must Remember. Deepika Serma mentions about Phule that "(...) she got the intersectionality. The Phule's vision of social equality included fighting against the subjugation of women (...)" (Collins\& Bilge:04). This woman is regarded as a firstgeneration modern Indian feminist who struggled with various social divisions that include caste, gender, religion, or class. Patricia, Sirma further asserts that "her political activism encompassed intersecting categories of social division -she didn't just pick one" (Collins \& Bilge:04). Her efforts include a protest shaving the heads of Hindu widows. She struggled for widow's remarriage in 1853 and initiated shelter for abandoned pregnant widows. Thus, 
people from diverse backgrounds use Intersectionality as an analytic tool in various ways to articulate a range of social issues.

Furthermore, the different analysis categories include race, class, gender, nation, or religion, which shows social division. In the words of Patricia," they are categories that gain meaning from power relations of racism, sexism (...) and class exploitation" (Collins \& Bilge:07). Thus, power relations are interconnected and contribute to forming these divisions. The four intertwined domains of power are interpersonal, disciplinary, cultural and structural. The core ideas of intersectional frameworks vary from project to project. However, the six core ideas provide a platform for thinking from an intersectional perspective: inequality, relationality, power, social context, complexity, and social justice.

One of the prominent literary scholars, Zia Ahmed, in one of his articles," Pakistan Feminist Fiction and the Empowerment of Women", mentions that "fiction is born out of the society (...), the representation of women emerges as the most significant aspect for the writers of English Fiction as a part of feminism" (Ahmed: 90). The modern Western writers like Virginia Woolf's "A Room of One's own" (1929) and Henrick Ibsen's "A Doll's House" (1879) or Jane Austen remarkable writings are among the prominent English fiction to develop a feminist awakening. The feminism trend gets a new dimension over the years, which is also visible in South Asian Literature written in English. The writers from this region are not unconscious of the dire need to address women discrimination and make the feminist approach evident in their writings. Zia Ahmed mentions Ashcroft, a literary scholar who says that "Literature offers one of the most important ways in which these new perceptions are expressed, and it is in their writings (...) that the day-today realities experienced by the colonized peoples have been most powerfully encoded and so profoundly influential" (Ahmed: 91). From Intersectionality's lens, an overwhelming silence and struggle of the sub-continent context women can be understood. The writers have portrayed these women characters who suffer due to religion, gender, social and cultural impositions. Zia Ahmed mentions Sara Sueri, who says, "women bodies were twice colonized, first by the British and then by the men in the Indo Pak Subcontinent" (Ahmed:92). Spivak, a feminist scholar, call this silent majority group of women "subaltern".

Writers like Bapsi Sidhwa, Mohsin Hamid, Arundhati Roy, Talat Abbasi or Bharati Mukherji are significant South Asian writers. The constant effort in portraying and unveiling 
women's sufferings in their writings establish a resistance within these marginalized groups. Bapsi Sidhwa is one of the prominent feminist voices from Pakistan in the world of diasporic English Literature. One of her novels, Water (2006), is based on Deepa Mehta's awardwinning film that explores the marginal and subaltern Hindu widows' life in India. The story provides an insight into the intersectional nature of the Indian Hindu widows in a patriarchal society of a subcontinent where different power domains hold and impose dominant hierarchies. It shows how power relations can manipulate cultural norms and use religion as a powerful tool to establish its hegemonic control over these marginalized widows who suffer as silent victims. It also focuses on how some women resist and challenge religious sanctions and empower themselves for progress and change.

\section{(III)}

"In our shared grief, we are all sisters here, and this ashram is our only refuge". (Water: 52)

The study of contemporary feminism within a framework of Intersectionality brings forth the systematic power structures that lead to women's exclusion on multiple dimensions. Chandra Mohanty, in one of her articles Under Western Eyes: Feminist Scholarship and Colonial Discourse, mentions Beverly Lindsay, who states that "linguistic and cultural differences exist between Vietnamese and Black American women, but both groups are the victim of race, sex and class" (Mohanty:339). So, Intersectionality's phenomenon uncovers the variety of cases and categories that makes these women "powerless". Zia Ahmed mentions Mohanty, who asserts that "Third World women, like Western women, are produced as subjects in historically and culturally specific ways by the societies in which they live and act as agents" (Ahmed:92). In this way, South Asian marginalized women's experiences also reveal specific privileged positioning and power networks responsible for their exclusion and oppression. In any context, women are positioned within a structured network of power relations that leads to oppression and struggle. The following textual analysis of the novel Water by Bapsi Sidhwa is based on interpersonal, disciplinary, cultural, and structural interconnected domains of power that use Intersectionality as an analytic tool in feminist studies.

\section{Interpersonal Domain of Power}


To examine the power structures in a particular context, the awareness and understanding of historical complexities, political and social knowledge are essential. The power through the kinship structure is usually exercised in the oppression of women in the sub-continent. Mohanty mentions Elisabeth Cowie, who suggests that "women as women are not located within family (...) it is in the family, as an effect of kinship structures, that women as women are constructed, defined within and by the group" (Mohanty:342). The kinship structures usually position men as a father, brother or husband in a privileged status to control women's lives as their wife, mother, sister, or daughter.

The novel opens with the same familial structure model where a dominating husband, Somanth persuaded his wife Bhagya to let their six-year-old daughter marry a forty-fouryear-old, Hira Lal. Somnath said to his wife that, "you are the wife and daughter of Brahmin priests, surely you are aware of our traditions. Outside of marriage, the wife has no recognized existence in our tradition". (Water:15). He further says about daughters that they are usually considered as "the burden of responsibility" (Water: 15). On the one hand, as a daughter, a woman's position seems to be of no value, she is merely a "burden", and on the other hand, the apparent status of a woman as a wife seems to be respectable. However, the submission of Bhagya constructs an entirely different view of a woman as a wife. She is an obedient wife who is bound by the man-made tradition and confesses that "It will be as you say-you are her father" (Water: 15).

Somanth pressurized his wife by giving religious reference that "in the Brahmanical tradition (...), a woman is recognized as a person only when she is one with her husband. Only then does she become a sumangali, an auspicious woman, and a saubhgyavati, a fortunate woman". (Water:14). These kinship structures suggest power relations about people's lives, who are advantaged and disadvantaged within interpersonal and a familial power domain. Thus, women positioned within the domestic system, regardless of being a wife, daughter or mother, are marginalized. "... the parents of a traditional Hindu bride have no rights over their daughter once she has been gifted to the bridegroom". (Water:28). The age-old customs that depict the controversial and deplorable state of widows in India during 1935 illustrate the patriarchal power structures. Within different domains of power, the positioning of women in family and Society is compelling and suggestive.

\section{Disciplinary Domain of Power}


UNIVERSITY OF CHITRAL JOURNAL OF LINGUISTICS AND LITERATURE

VOL. 4 | ISSUE II | JULY - DEC | 2020

When it comes to the power structure and functioning, people find themselves encountering different positions and treatment. Within the disciplinary domain of ashram (place for Hindu widows), power operates when there is a binary division of domination and exploitation. In a place like an ashram, Madhumati, who was "clearly the ruler of the dilapidated ashram" (Water:51), dominates the other widows. A playful Chuiya at the age of nine was abandoned and transferred to a miserable ashram (a place for widows), "her cries were interrupted by a loud command. Quiet! Shut her mouth" (Water:51). Madhumati, a vicious widow within a stern authority, operates the place and discipline other widows. The writer depicts widows' miserable lives like Chuyia, Kalyani, Madhumati, Shakuntala, Kunti and Pattirajji. These main women characters, including others, were destined to suffer in the same plight, but Madhumati, the ashram's head, defines other widows' position. The profound scholars Patricia and Sirma writes that "Power is better conceptualized as a relationship (...) than as a static entity. Power is not a thing to be gained or lost (...) it constitutes a relationship" (Collins \& Bilge: 28). Thus, Madhumati seems to be a distinctive category to power differences within a community of widows. It gives an inclusive viewing of a disciplinary domain of power. As Bua told Chuyia," ( Madhumati) family donated to a temple in the city: that's why "Fatty" is the head of the ashram" (Water:56).

The power structures within the ashram also reveal the reasons for subjugation. These widows became the victim of forced patriarchal demands on their body by giving reference to the Hindus holy texts and compelling them to fulfil the physical need of landlords and priests. At Kalyani's young age death, Shakuntala told Narayan that, "Disguised as religion, it's just about money" (Water: 209), and it is evident in all the ill practices. Shakuntala, one of the most powerful characters of the novel, before realizing and discovering the hypocrisy in the name of religion, used to follow what scriptures say, "she had never questioned the belief in the Dharma Shastra that widowhood was the punishment for a sinful existence in the past, (...)" (Water:66). The feeling of repentance imposed on her and other widows further disintegrate them.

Chandra Mohanty mentions that "Patriarchy is always necessarily male dominance, and the religious, legal, economic and familial systems are implicitly assumed to be constructed by men" (Mohanty:350). The novel reinforces Mohanty's idea of male domination in a familial structure. Despite Bhagya strong reservations, her husband Somanth 
decided to marry her six-year-old daughter to a forty-four-year man. Furthermore, he leaves her grieving daughter in the ashram, a place for widows, where all widows undergo hardships and humiliations. Chuyia pleaded to her father that, "Baba don't leave me. Somanth stood helpless, resigned to his fate and fate of his daughter" (Water:50). The rigid conventions and orthodox beliefs in a patriarchal kinship system mainly designate or positioned a man as a husband, brother, father, or son who apply specific disciplinary rules on their family that includes only women, and men are exempted from everything. Like Chuyia father, the Shakuntala brothers also abandon their sister into the ashram. "(Shakuntala) brothers made arrangements for her to go to the ashram (...)" (Water:176). Regardless of their differing positions, "power is automatically defined in binary terms: people who have it (men) and people who don't have it (women)" (Mohanty:344).

\section{Cultural Domain of Power}

The novel depicts that certain cultural, religious, and ideological specificities are responsible for marginalizing a group of Hindu windows and making them powerless. The intersectional analysis focuses that social inequality, power and a particular social context are interconnected. In the words of Patricia\& Sirma, "fairness is elusive in unequal societies where the rule may seem fair, yet differentially enforced through discriminatory practices" (Collins\& Bilge:29). Similarly, the orthodox, tradition-bound Indian Society is structured on religion that makes and implement inhuman rules and practices only on women. Bapsi Sidhwa gives an insight into such deep-rooted violence and ill practices on Hindu widows in her novel Water. The writer displays Bhagyas similar concerned for her daughter future. She knows that "(...) in Barhamin culture, once widowed, a woman was deprived of her useful function in society $(\ldots)$ she ceased to exist as a person (...) there was no place for her in the community, and she was viewed as a threat to society" ( Water:32 ).

In Hindu tradition, the widows had limited choices. During the colonial era, the Britishers abolished one of the ill practices of sati, burning a widow alive with her dead husband. One of the analysis on Spivak essay Can Subaltern Speak? by Eleanor Ross who writes about this ill practice that "the ritual of Sati (burning of widows alive) is represented as removing the widow's identity: she exists in relation to her deceased husband, who retains his "power beyond the grave". (Ross: 387). Unfortunately, even after the abolishment of sati, women's subjugation continued but in a different form. The fundamental religious and 
cultural complexities characterize the lives of these Hindu widows that define men as "subjects who perpetrate violence" (Mohanty:339).

. The setting of Water depicts an era of 1938 when the Subcontinent was under colonial rule. The Muslims and Hindus of the Subcontinent were struggling for freedom from the Britishers. However, the Hindu widows are deprived of fundamental human rights and are further dragged into the deplorable state for the rest of their lives in the ashram. These women were bound to believe, as Madhumati said to Chuyia that, "our Holy Book says a wife is a part of her husband while he is alive. (...) and when our husbands die (...) wives also half die". (Water:52). It is reinforced when one of the characters, Shakuntala, became a widow,"(her) head was shaved to remove the sin and pollution in her hair (...) as she (her mother-in-law) broke the glass bangles and ripped off the mangal sutra from her neck in the first rites marking her passage into widowhood". (Water: 175). The novel reveals that the unthinking adherence to the religious scriptures only disintegrates these women. It increases the cultural domain of power. Thus, "social inequalities that are fairly produced are socially just "(Collins\& Bilge:11). The novel mainly exposes the cultural environment of power, which is triggered by the manipulation of religion. Fathers and brothers took their daughter and sister to the ashram despite knowing the place's distress and severance.

\section{Structural Domain of Power}

The intersectional analysis within academic and political context reveals that the Black women movement emphasized the structures that cause inequality. They focused on the role of power relations that operate within specific organizations and institutions responsible for marginalizing women on various levels. In one of the articles Towards a Field of Intersectionality Studies: Theory, Applications and Praxis, Crenshaw states that "(...) the overlapping structures of subordination revealed how certain groups of women were made particularly vulnerable to abuse (...) (Sumi, Crenshaw \& McCall:797). Similarly, the novel Water reveals a sheer failure of the religious institution (ashram, a place for widows) that normalizes Hindu widows' exclusion. Such "structural intersectionality" seems to reach the largely unchecked powers that normalized unjust domination. In one of the articles, P Sobharani mentions Halting, who introduced and defined structural violence in 1969 that "(It is) an avoidable impairment of fundamental human need" (Sobharani:691) 
One of the heartbreaking stories of Shakuntla depicts structural violence. She was initially mistreated by her in-laws when she became a widow at thirty and was later dragged by her brothers into the ashram. "..... (she) could cover her body with only a piece of white cloth, she was essentially slowly starved (...) was limited to one meal a day (..) had to sleep on the ground". (Water: 175). She blindly followed religious scriptures and endured familial and ashram ill-treatment considering "widowhood" a punishment for women. The ashram had a legal status with a tremendous influence of power relations that control all the widows physically and economically in the name of religion. A nine-year-old Chuyia was brought to the ashram, who was instructed to wrap her body with an unstitched piece of white cloth. "You can't wear colours or stitched clothes", Madhumati further said, "I told you widows are not permitted to wear stitched clothes". (Water: 42). Dr Veena R llame writes in one of his articles Bapsi Sidhwa Water: Pang of Widowhood, that "the condition of the widow is dreary as they become soft targets for men of the upper caste and priests" (Dr Veena: 922). These widows receive inhumane treatment either in the name of Brahmanical tradition or religious manipulation. The helpless widows were forced to shave their heads, destined to suffer in isolation and compel to beg for their survival. "(The widows) ... sat outside the temples in their white saris with their begging bowls. They had grown accustomed to begging as they had to the gruelling hours of singing in temple halls to earn a few coins and a fistful of rice" (Water: 117). Furthermore, "....in a singing ashram-temple (...) when a widow was too sick to perform, she starved" (Water: 60). Thus, the Brahmin ideology is reduced to ideas that form and apply rules on women only. Such doctrines seem to have legal protection, as corruption is oversight by government institutions and organizations. It also suggests empowerment of the ashram's structural system (a place for widows) that reflect violent oppression.

\section{(IV)}

Using Intersectionality as an analytic tool by many feminists are no more limited to Black women, women of ethnic minorities or the marginalized one. One of the scholars, Nira Yuval-Davis, mentions Harraway in one of her articles Power, Intersectionality, and the Politics of Belonging, says, "Epistemologically intersectionality can be described as the development of feminist standpoint theory(..)"(Nira Yuval: 3). With each new intersection, its open-end approach, the study provides a comprehensive and reflexive insight to various 
inquiries. In the words of Crenshaw, "using intersectionality(is)useful for understanding connections between individuals lived experiences, socially structured institutional arrangements and collective mobilizations" (Kathy Davis: 75). Thus, the study aims to understand and analyze people's complex lives in a complex and challenging social context. People experience different forms of social inequality or see around themselves, and "recognizing social inequality is rarely caused by a single factor" (Collins\& Bilge:26). Kimberle Crenshaw, in 1989 has introduced the term to address the discrimination and struggles of Black women's experiences. However, Crenshaw is not the first to address the women's subjugation and exclusion experiences within feminist discourse. The world feminist scholars from the Atlantic and Third World have highlighted women of colour's oppression and backgrounds.

Similarly, women's struggle across classes and cultures in feminist discourse may differ on a vision of equality, and every experience of oppression may vary. Though race, class, gender, capitalism, or nation, among others, are intertwined or mutually constructed. However, religion is also one of the vital factors that also create or intersect the power system. Mohanty mentions in Under Western Eyes: Revisited: Feminist Solidarity through Anticapitalist Struggles that "the rise of religious fundamentalisms with their deeply masculinist and often rhetoric poses a huge challenge for feminist struggles around the world" (Mohanty: 508)

The fiction writers from Pakistan and India have also portrayed women's lives in preand post-partition of the Subcontinent. The women are usually victimized under the strict laws of religion and Society imposed by men. Zia Ahmed writes that "(women) are depicted (...) by the demons of social taboos which are man-made and used to control the lives of women" (Ahmed: 92). He further states that "the Muslims and Hindu religion further contributed to making these taboos even stronger" (Ahmed:92). The novel Water by Bapsi Sidhwa reflects power structures that are interpersonal, cultural, disciplinary, and structural. Using Intersectionality as a heuristic or analytic tool provides an insight into these domains that control women lives by manipulating religion. Furthermore, it proves that the feminist debate within a framework of Intersectionality has a significant place in Pakistani fiction written in English. 


\section{Works Cited}

Ahmed, Zia. "Pakistani feminist fiction and the empowerment of women." Pakistaniaat: A Journal of Pakistan Studies, vol:1, no:2,2009, pp: 90-102.

Arafat, Yasir, Sharjeel Ahmad, \& Muntazar Mehdi. " Totalitarianism and Colonial Legacy: A Postcolonial Analysis of Muhammad Hanif's A Case of Exploding Mangoes." University of Chitral Journal of Linguistics \& Literature [Online], 4.I (2020): 31-37. Web. 25 Mar. 2021

Bilge, S. "Intersectionality undone saving Intersectionality from feminist intersectionality studies. Du Bois Rev, vol:10, no:2,2013, pp: 405-424.

Cho, Sumi, Kimberlé Williams Crenshaw, and Leslie McCall. "Toward a field of intersectionality studies: Theory, applications, and praxis." Signs: Journal of women in culture and Society, vol:38, no:4 2013, pp: 785-810.

Collins, Patricia Hill, and Sirma Bilge. Intersectionality. Polity Press, 2016: pp:1- 23.

Davis, Kathy. "Intersectionality as buzzword: A sociology of science perspective on what makes a feminist theory successful." Feminist theory, vol:9, no:1 ,2008, pp: 67-85.

Ross, Eleanor. "In" Can the Subaltern Speak? ', Spivak offers the sentence" White men are saving the brown women from brown men 'as one interpretation of the relationship between colonizer and colonized. How far does this sentence reflect the representations of British dealings with India in the texts you have studied?." The University of Nottingham School of English Studies vol:2,2009-2010,pp:385-395

Ilame, Veena R. "Bapsi Sidhwa's Water: Pangs of Widowhood." International Journal of English Literature and Social Sciences: vol:5, no:4, 2020.pp:921-925.

\section{https://ijels.com/}

McCall, Leslie. "The complexity of intersectionality." Signs: Journal of women in culture and Society, vol:30, no:3,2005, pp: 1771-1800.

Mohanty, Chandra Talpade. "Under Western eyes: Feminist scholarship and colonial discourses." Boundary, vol:2 ,1984, pp:333-358. 
Mohanty, Chandra Talpade. "Under western eyes" revisited: Feminist solidarity through anticapitalist struggles." Signs: Journal of Women in Culture and Society, vol:28, no:2,2003, pp: 499-535.

Rasool, S. H. et al. "Subverting the British Raj: Delhi as a Metaphor of Resistance in Ahmad Ali’s Twilight in Delhi (1940)", The Discourse, Vol 05,Issue 02, July-Dec, 2019

Sidhwa, Bapsi. Water: A Novel, Milkweed editions,2006.

Sobharani, P. "Widow's rebel against Structural Violence of Patriarchy in Bapsi Sidhwas Water: A Critical Outlook". Research Journal of English Language and Literatures, vol:5, no:1,2017.pp:691-693

Yuval-Davis, Nira. "Power, Intersectionality and the politics of Belonging.". FREIA. Department of Culture and Global Studies.no:75, 2011.pp:1-25

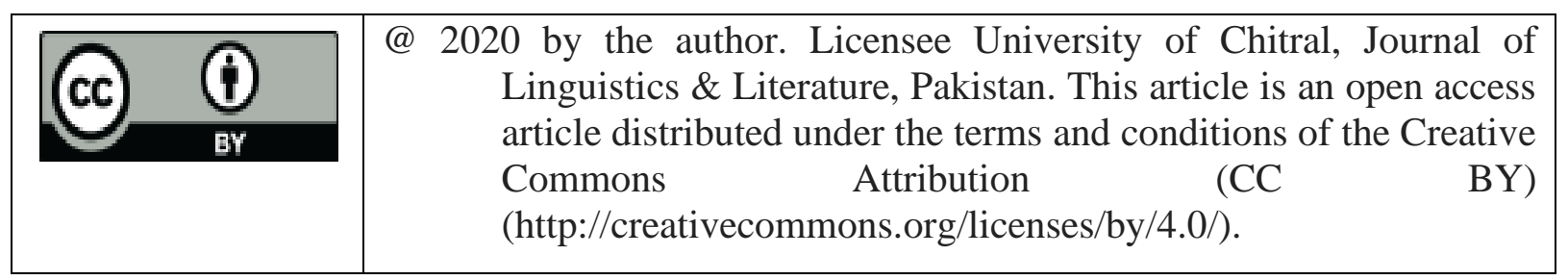

